\title{
On Innovation of Ideological and Political Education of the Students in Privately-run Higher Learning Institutions
}

\author{
Fengzhen Jia \\ Shaanxi province of Xi'an city Changan District Xijing Road No. 1 Xijing University, 710123 \\ jiazhen8588@126.com
}

Keywords: Privately-run higher learning institutions; College students; Ideology and politics; Education

\begin{abstract}
At present, the ideological and political education of college students has received unprecedented attention. On the one hand, the ideological and political education of the students in privately-run higher learning institutions reflects the general rule of the ideological and political education of college students. On the other hand, it has the peculiarities of its own. The article makes the analysis of the problems in the ideological and political education of the students in privately-run colleges and universities before putting forth related innovative approaches by combining realities.
\end{abstract}

Importance and Necessity of the Ideological and Political Education of the Students in Privately-Run Higher Learning Institutions

Importance of the Ideological and Political Education of the Students in Privately-Run Higher Learning Institutions. China is undergoing a critical period of socialist transition, which will bring about a new round of upgrading of industrial structure and urgently need a large number of high-level and high-caliber professional talents. Like governmental colleges and universities, privately-run colleges and universities also shoulder the important mission of cultivating qualified builders and reliable successors. Strengthening the ideological and political education of the students in privately-run higher learning institutions constitutes the strategic requirement to attain national rejuvenation and prosperity, the requirement of society for overall development of talents and the intrinsic requirement to realize scientific development concept and constitute harmonious society. Therefore, it is necessary to enhance the ideological and political education of the students in privately-run colleges and universities.

Necessity of the Ideological and Political Education of the Students in Privately-Run Higher Learning Institutions. Due to school-running system and mechanism, some privately-run colleges and universities are confronted with such problems as inadequate attention paid to the ideological and political education of students, lack of methods, weakness of teaching staff, low quality and loose combination with reality. The formation of the mechanism of sharing educational cost as well as the in-depth reform of graduate employment system has raised a higher demand for students' education, management and service. The ideological and political education of present privately-run colleges and universities is facing a grave challenge. Therefore, non-governmental colleges and universities should actively explore the new content, new mechanism and new methods of ideological and political education suitable to the characteristics of privately-run higher learning institutions and educational rule by adopting the attitude of being responsible to society and students and putting first the enhancement of the ideological and political education of college students.

\section{Problems in the Ideological and Political Education of the Students in Privately-Run Higher Leaning Institutions}

In Spite of Their Relatively Complete System of Ideological and Political Education, Privately-Run Colleges and Universities are Weak in Overall Strength. Unbalanced development is a universal phenomenon of privately-run schools. Especially in the past few years, 
for their own survival, privately-run colleges and universities have been constantly expanding their enrollment scale, enhancing hardware facility construction and logistics services so as to ensure the continuous increase of their economic benefits. However, little attention has been paid to the construction of ideology and politics, leading to the continual weakness of the ideological and political education of the students in privately-run colleges and universities. As far as the team of ideological and political education in private schools is concerned, further improvement should be made both in faculty and in the setup of related institutions. The following phenomena are popular among privately-run higher learning institutions. Firstly, the expenditure for ideological and political work is serious insufficient. Secondly, the study on moral education means lags behind that on professional teaching means. Thirdly, class teacher and tutorial system are not put in place, only relying on the teachers of ideological and political theory course to finish the ideological and political education of students while other teachers simply complete their teaching work. The lack of the special research centering on the ideological problems of the students in privately-run higher learning institutions and their ways of resolution leaves the ideological and political education of the students in such colleges and universities basically in the state of isolation.

It is Rather Difficult for Privately-Run Higher Learning Institutions to Pay Attention to Ideological and Political Education. Generally speaking, private schools boast more part-time teachers than full-time teachers, which will form the phenomenon characterized with "separation of management from teaching and teaching without education". Though quite a few of part-time teachers are earnest, responsible and high-caliber, they are different from full-time teachers after all. The idea of employment and temporary concepts are universally popular among them. In most cases, they only put stress on teaching rather than education. Moreover, due to the insufficiency of faculty, privately-run higher learning institutions excessively rely on and accommodate themselves to these teachers. As a result, some teachers shut their eyes to the misconducts of students in class, thus leading to the situation where the students are more and more unrestrained and more and more difficult to control.

It is Difficult for Privately-Run Schools to Form a Systemic Mechanism of Ideological and Political Education. In spite of the fact that privately-run colleges and universities have their team of ideological and political education, the majority of the team are part-time. Most of the teachers in such colleges and universities are part-time and in some of such colleges and universities even class teachers are part-time, let alone having full-time instructors, which makes it hard for such colleges and universities to form a systemic mechanism of ideological and political education. The problems facing privately-run schools such as a loose team of teachers, an unsound management mechanism and excessive attention to economic interests not only intensify students' commercialized awareness but also make it more and more difficult for these schools to conduct ideological and political education. In this case, such schools are hard to form a stable team of political work.

There are Problems in the Channels of Ideological and Political Education on the Part of Privately-Run Higher Learning Institutions. The ideological and political education of the students in privately-run higher learning institutions has the following channels. Firstly, in terms of the ideological and political education of the students in privately-run colleges and universities, the most direct way is to teach students the knowledge of political theory through classroom education and guide them to transform the knowledge into their external behaviors and habits by way of teacher' s explanation to let them make self-cognition and self-evaluation in an objective way and further produce their internal requirement featuring self-discipline and self-improvement so as to form the mechanism of moral self-discipline as far as the students in private colleges and universities are concerned. Secondly, the education and communication conducted by the instructors in privately-run higher learning institutions are the universal mode of ideological and political education in such higher learning institutions. The instructors in privately-run colleges and universities are faced with the students who are inferior to their counterparts in state-run colleges and universities as far as school record is concerned. Psychologically, they are universally beset by the sense of loss and short of consciousness and persistence in study. Instructors can only realize the objective of ideological and political education through class meetings, collective activities and 
heart-to-heart talks with the students. Thirdly, the Party and League organizations or student societies in privately-run colleges and universities organize some activities or conduct some publicity according to requirements, for example, putting up some posters about ideological and political education in the bulletin board or some familiar slogans. However, in most cases, such channels about the ideological and political education of the students in private colleges and universities become formalistic without playing substantial functions.

\section{Approaches to the Ideological and Political Education of the Students in Privately-Run Higher Learning Institutions}

Resolute Measures are taken to strengthen the Leadership and System Guarantee of the Ideological and Political Education of the Students in Privately-Run Higher Learning Institutions. If the ideological and political education of the students in privately-run higher learning institutions is to be raised in a substantial way, the following aspects should be done well. Firstly, incorporate the ideological and political education of the students in privately-run higher learning institutions into overall planning, strengthen macroscopic leadership, organize work exchanges and supply supports in aspects such as scientific research. Policy support should be given to the activities of ideological and political education of college students and evaluation and appraisal should be carried out toward the ideological and political education of college students at regular intervals. Secondly, the Party organization and main Party and administrative leaders of privately-run higher learning institutions should pay high attention to the ideological and political education of college students and regard it as the top priority of cultivating the builders and successors of socialist cause. The main Party and administrative leaders of privately-run higher learning institutions are the chief responsible persons of the ideological and political education of college students. They should conduct comprehensive analysis and research of the ideological and political education of college students and put forth relevant enforcement measures and improvement suggestions. Thirdly, privately-run colleges and universities should provide necessary financial support for the ideological and political education of college students. As a rule, the fund used in the ideological and political education of college students should be no less than $3 \%$ of the operating expenses and the total payment of students. Modern educational facilities suitable to college students should be constructed and funds investment should be guaranteed to create good material conditions for the ideological and political education of college students.

A highly-qualified and High-Efficient Team of the Ideological and Political Education of Students Should Be Built Up. As an important force in the field of quality-oriented education, the team of ideological and political work constitutes a pivotal hinge coordinating schools, families and society, which requires a firm political standpoint, good service awareness, profound knowledge and learning as well as strong responsibility on the part of the educators engaging in ideological and political work. If such a team of ideological and political education is built up, the following aspects should be taken into consideration. Firstly, great efforts should be made to reduce the flow of teaching staff and construct a team of full-time teachers devoted to ideological and political education with the allotment of excellent full-time class instructors. Grade office should be set up to intensify the function of ideological and political work on the part of the Party Committee of school. Secondly, encourage faculty members to continuously strengthen self-cultivation and upgrade individual comprehensive quality. In accordance with their working realities, teachers should master the formation and development of creativity through their experiences and construct the cultivation of creativity on the scientific base. Only in this way can traditional teaching methods be forsaken to carry out work in a creative manner. Thirdly, teachers should change the standard for evaluating students. Under the long-term influence of exam-oriented education, people are accustomed to taking the amount and depth of knowledge as the yardstick for evaluating students, which will lead to the phenomenon characterized with high marks but low ability. Teachers should change this concept to set up the evaluation standard with the focus on man's comprehensive quality and the integration of knowledge instruction, ability training and quality education. Finally, a team of ideological and political educators who are expert at both politics and specialties and love 
students should be built up.

Continuously innovate on and expand the Channels for the Ideological and Political Education in Privately-Run Higher Learning Institutions. The ideological and political education should be conducted in a multi-channel mode by combining the peculiarities of privately-run colleges and universities. According to the characteristics of students, the instructors of privately-run higher leaning institutions should set up different contents and goals specific to different student groups by adopting the method of "using teaching methods best adapted to students." For the student group with Party members as the majority, high standards and strict requirements should be insisted. As with common students, honesty and trustworthiness, assiduous study and mutual help should be advocated. As for freshmen, graduates and the students with mental disorders, ideological and political work should be carried out in an active way. Instructors should understand the importance of the construction of their team from the perspectives of ideological and political education and social stability. The Party and League organizations as well as student societies in privately-run higher learning institutions should regard ideological and political education as a long-term and meticulous task. The grass-root Party organizations of privately-run higher learning institutions should be established and improved. In addition, measures should be taken to regulate the normal operation of the activities of the Party organizations and Party members. Party members should be actively admitted and new educational modes and methods should be brought forth constantly.

\section{References}

[1] Q.Li: Private colleges and universities student management work is analyzed [J].Forum on Contemporary Education,2011(9).(In Chinese)

[2] L.Zhuo: Private colleges students education and management present situation and countermeasure research[J].Teaching management,2010(3).(In Chinese)

[3] B.S.He: Private colleges to strengthen and improve ideological and political education[J],commercial economy,2010(4).(In Chinese)

[4] J.Sun: Attaches great importance to strengthen the party building of private colleges and universities ideological and political work and the moral education work[J],China's higher education research,2012(1).(In Chinese) 